\title{
Jews, Real and Imagined, at San Isidoro de León and Beyond
}

\author{
Julie A. Harris
}

\begin{abstract}
From the tenth to the fifteenth centuries, medieval León possessed a thriving Jewish community whose presence can be traced via archaeological and documentary remains. As regards the treasury of San Isidoro de León, however, there is no evidence for the involvement of living Jews with its luxury objects - an involvement that has been documented in comparable centers elsewhere in Iberia and Europe. Apart from a possible but unproven relationship to its textiles, a Jewish connection to the treasury of San Isidoro remains ideological and limited to the presence of Abraham's relics in a single object. However, both living and ideological Jews can be associated with León's cathedral, where a portion of the Jewish community's annual taxes was earmarked to light its altars and where the sculptural program featured the blind Synagogue.
\end{abstract}

\section{Keywords}

San Isidoro(León) - Jews - León - synagogue of León-Urraca-Toledo - textiles - relics

Almost nothing of the built environment of León today bears witness to what was once its vibrant Jewish community. A solitary street marker with the name Calle Prado de los Judíos marks the area near the walls in which León's Jews once tended their gardens and grazed their flocks. Unlike Toledo or Córdoba, cities whose extant synagogues and mosques attract visitors in search of a multi-cultural landscape, León's face is that of Christian Spain. Her primary tourist attractions - the royal pantheon at San Isidoro and the Cathedral of Santa María de la Regla—offer magnificent examples of Romanesque and Gothic architecture. Their sculptural programs, painted decor, and deluxe 
liturgical objects proclaim a confident theology from which living Jews were excluded-save in their role, as set forth by Augustine, as witnesses to the truth and triumph of Christianity. ${ }^{1}$

Yet, there is plenty of evidence for the presence of Jews in and around León in the Middle Ages: epigraphic evidence on surviving gravestones, documentary evidence preserved in the archives of the Cathedral, archaeological evidence yielded by recent exploration of the adjacent area known as the Castrum iudeorum or Puente Castro. All attest to a thriving Jewish community in the region from perhaps as early as the tenth century. ${ }^{2}$ The content of Alfonso V's 1017 fuero for the city of León suggests that there was already an established Jewish community at that time. ${ }^{3}$ The archive of the Cathedral contains seven documents, written in Hebrew by Jewish scribes, recording sales of vineyards

1 This research was funded by The Medieval Treasury across Frontiers and Generations: The Kingdom of León-Castilla in the Context of Muslim-Christian Interchange, c. 1050-1200 (PI, Therese Martin, Spanish Ministry of Economy and Competitivity, HAR2015-68614-P), and the Princeton Institute for International and Regional Studies at Princeton University. There is a lengthy bibliography on Augustine and the Jews. Especially helpful is Jeremy Cohen, Living Letters of the Law: Ideas of the Jew in Medieval Christianity (Berkeley: University of California Press, 1999).

2 The most comprehensive and interdisciplinary treatment of León's Jewish community is Justiniano Rodríguez Fernández, La judería de la ciudad de León (León: Centro de Estudios e Investigación San Isidoro, 1969). The earliest document included in this volume dates from 905 and refers to a convert: "Nabaz quondam iudeus, postea vero christianus et monachus," document 1, 165. See also Francisco Cantera Burgos, "Juderías medievales de la provincia de León," Archivos Leoneses 55-56 (1974): 85-155. Additional gravestones from the Puente Castro cemetery were discovered after the publication of Rodríguez Fernández's book. The group was discussed most recently in Jordi Casanovas Miró, Las inscripciones funerarias hebraicas medievales de España (Monumenta Palaeographica Medii Aevi: Series Hebraica) (Turnhout: Brepols, 2004), 152-162. Isolated examples are discussed elsewhere, for example: Javier Castaño and José Luis Avello, "Dos nuevos epitafios hebreos de la necrópolis del Castro de los Judíos (Puente del Castro, León)," Sefarad 61/2 (2001): 299-318; and in Memoria de Sefarad (Toledo: Centro Cultural San Marcos, 2002), cats. 164-165, pp. 214-217, for a description of the excavations with additional bibliography. For the archives of the Cathedral, see Colección documental del archivo de la catedral de León, 17 vols. (León: Centro de Estudios e Investigación San Isidoro, 1987-1997). For archaeology, there is the work of Raquel Martínez Peñín, especially "La Judería altomedieval de la ciudad de León: Fuentes documentales y datos arqueológicos," Miscelánea Medieval Murciana 31 (2007): 123-138.

3 The fuero, or city law code, required that a free tenant wishing to sell a house built on land owned by another secure assessments of its value by two Christians and two Jews. Baer interpreted the fuero as implying that Jews living on rural properties had the same interests and rights as Christians in similar circumstances. Yitzhak Baer, A History of the Jews in Christian Spain, 2 vols. (Philadelphia: Jewish Publication Society, 1992), 1:44: see also Maya Soifer Irish, Jews and Christians in Medieval Castile: Tradition, Coexistence, and Change (Washington, D.C.: Catholic University Press, 2016), 54-55. 
by Jews of the "castle" to Christians — both lay people and clergy. ${ }^{4}$ This particular community located on the outskirts of León, however, suffered a major setback in July of 1196 when the castrum was destroyed by followers of Alfonso VIII of Castilla and Pedro II of Aragon who were unified in battle again the Leonese. ${ }^{5}$ In 1197, a year after the attack, property that once belonged to Jews was given by Alfonso IX, king of León, to the city's Cathedral. ${ }^{6}$ The surviving members of the community relocated to León proper, settling in highest numbers on the south side of town in the area around what is today known as the Plaza de San Martín. Documentary evidence has revealed at least one synagogue located on the Calle de la Misericordia (then known as the Cal de Moros). ${ }^{7}$ According to historian Maya Soifer Irish, however, surviving documents from the judería of León reveal a robust real estate market characterized by Jews and Christians living in integrated neighborhoods. ${ }^{8}$ By the late fifteenth century, the Jews of León were subject to legislation that sought to restrict their use of public space. ${ }^{9}$ The final securely dated document published in Justiniano

4 Javier Castaño, "Los documentos hebreos de León en su contexto prenotarial," in Judaismo hispano: Estudios en memoria de José Luis Lacave Riaño, ed. Elena Romero (Madrid: Junta de Castilla y León, 2002), 2:459-481.

5 Rodríguez Fernández, La judería de la ciudad de León, 33-36, discusses the destruction of the Castro de los Judíos and its treatment in various narrative sources. According to Abraham Zacuto (Sefer Yuhasin, 1504) the famed - and possibly legendary-Hilleli Bible was taken by raiders at this time. Part of the bible was copied in Toledo in 1241 and is believed to have been the model for a manuscript of the Pentateuch in the Jewish Theological Seminary (MS L44a). See David Stern, "The Hebrew Bible in Sepharad: An Introduction," in Biblias de Sefarad, ed. Esperanza Alfonso, Javier del Barco, María Teresa Ortega Monasterio, and Arturo Prats (Madrid: Biblioteca Nacional de España, 2012), 49-86 at 62, who incorrectly connects the raid to the Almohades. See also B. Pick, "Lost Hebrew Manuscripts," Journal of the Society of Biblical Literature and Exegesis 2/2 (1882): 122-127.

6 Rodríguez Fernández, La judería de la ciudad de León, 192, doc. 59. Soifer Irish, Jews and Christians, 62 , n.48.

7 Rodríguez Fernández, La judería de la ciudad de León, Chpt. 3 provides a history of the relocated aljama in the city proper. Evidence for the synagogue's location is presented, 104-112. The author also discusses the possibility that the Puente Castro survivors joined an already extant community within León, 61. For the fate of the synagogue after the Expulsion, see Yolanda Moreno Koch, "El destino de la sinagoga mayor de León después de la Expulsión," in Homenaje al Profesor J. Cantera (Madrid: Universidad Complutense, 1997), 63-66; and Ricardo Muñoz Solla, "Nuevas noticias sobre la sinagoga mayor de León," Estudios Mirandeses 25 (2005): 131-149, presents scholarly arguments (with additional bibliography) regarding the synagogue's putative location.

8 Soifer Irish, Jews and Christians, 71.

9 An act issued by the Cathedral on July 20, 1481 (Sobre la mudanza de los Judios) sought to move León's Jewish community to a less centralized quarter of the city so they would not frequent the streets on which Christian processions ocurred. Rodríguez Fernández, La judería de la ciudad de León, 102. 
Rodríguez Fernández's study of Leon's judería mentions no living Jews. Dated to 1488 , the document records the sale of an orchard near a house that was once a synagogue. ${ }^{10}$

Thus, the narrative of Jewish life in León, constructed by written documents and material culture, reveals a community whose fate is similar in many ways to others in Iberia: there are moments of peace and prosperity under a tolerant ruler, there are moments when the community bears the brunt of social discord or civil war, there is recovery followed by decline. There is, of course, the expulsion.

Despite a familiar trajectory and a relatively rich cache of information regarding Jewish León, one looks in vain for examples of the sort of involvement of Jews with luxury objects found elsewhere in Iberia and Europe. This involvement has been carefully documented by Joseph Shatzmiller and other historians whose archival research has revealed the interactions between Jewish moneylenders and church authorities in need of currency.11 In Iberia, the activities of Jewish moneylenders took literary form as a story line in the Poem of El Cid. ${ }^{2}$ They took visual form, too, generating imagery such as that found in the late thirteenth-century manuscript of Aragonese feudal customs known as the Vidal Mayor. ${ }^{13}$ Of the four miniatures featuring Jewish figures, three depict their commercial involvement with precious metal objects (fols. $114 \mathrm{r}, 18 \mathrm{or}, 175 \mathrm{v}$ ) while the fourth depicts Jews as metalworkers (fol. 243v). ${ }^{14}$ As

10 Rodríguez Fernández, La judería de la ciudad de León, 252, doc. 143. In his book's epilogue, the author discusses the sources pertaining to León's Jewish community in the late fifteenth century. It is estimated that between four hundred and six hundred Jews were living in the city of León at the time of the expulsion: see Isidoro González Gallego, "Los últimos años de las aljamas leonesas," Archivos Leoneses 42 (1967): 372-407.

11 Joseph Shatzmiller, Cultural Exchange: Jews, Christians, and Art in the Medieval Marketplace (Princeton: Princeton University Press, 2013). Jacob Katz, Exclusiveness and Tolerance:Studies inJewish-GentileRelations in MedievalandModern Times (Oxford:Oxford University Press, 1961), 27-34 and 38-47, discussed how medieval Ashkenazi communities creatively managed their contact with Christian liturgical objects within the bounds of Jewish law.

12 In the first Cantar, El Cid dupes the Jewish moneylenders Raquel and Vidas of Burgos. Rita Hamilton and Janet Perry, trans., The Poem of the Cid (London: Penguin Books, reprint 1987), 27-33.

13 J. Paul Getty Museum, Ms. Ludwig XIv 6, 83.MQ.165. The most comprehensive publication of this manuscript is A. Ubieto Arteta, J. Delgado Echeverría, J.A. Frago Gracia, and M. del C. Lacarra Ducay, Vidal Mayor: Estudios (Huesca: Instituto de Estudios Altoaragoneses, 1984).

14 Vivian Mann, Thomas Glick, and Jerrilynn D. Dodds, eds., Convivencia:Jews, Muslims, and Christians in Medieval Spain (New York: George Braziller and The Jewish Museum, 1992), 194-195, cat. 24 . 
discussed by Pamela Patton, the illumination on folio $175 \mathrm{~V}$ which introduces a chapter "On Usury," features the exchange of a golden chalice for a bag of coins between a Jew and a Christian (Figure 8.1). ${ }^{15}$ Another miniature with outwardly similar iconography appears on folio 18or marking the chapter entitled "On Trickery;" in this case the narrative involves a less straightforward exchange. ${ }^{16}$ Sentiments regarding Jews, their access to and familiarity with Christian liturgical vessels, may also have infiltrated a scene in the fourteenthcentury Golden Haggadah, which depicts the Spoiling of the Egyptians during the Israelites' Exodus. In the miniature, the spoils taken by the fleeing Israelites (Exodus 12:36) bear a striking resemblance to objects in contemporary church treasuries (Figure 8.2). ${ }^{17}$

From León, however, there is none of this. No documentary or visual evidence presents Jews acting as recipients of church treasures pawned in return for more disposable wealth. ${ }^{18}$ The closest we come to this scenario is the presence of local Jews, who—along with their Christian neighbors—witness two instances of Queen Urraca's confiscation of liturgical vessels from the monastery of Valcavado. In the first, dated 1115 , Urraca enlists the help of a local magnate and his wife to obtain a number of silver objects to be exchanged for a quantity of money. In the second instance, dated 1116, Urraca demands the cross that her aunt the Infanta Elvira had donated to the monastery. ${ }^{19}$ The

15 Pamela A. Patton, Art of Estrangement: Redefining Jews in Reconquest Spain (University Park, PA: The Pennsylvania State University Press, 2012), 57-59.

16 Patton, Art of Estrangement, 61. See also Shatzmiller, Cultural Exchange, 38-40, for discussion of the miniature on folio 114 .

17 Julie Harris, "Polemical Images in the Golden Haggadah, BL, Add. MS 27210," Medieval Encounters 8 (2002): 105-122; Shatzmiller, Cultural Exchange, 40-41.

18 However, a Hebrew grave marker from Puente Castro, dated to 110o, has been translated as naming the deceased as Joseph, son of Aziz the silversmith. Rodríguez Fernández, La judería de la ciudad de León, gravestone number 3, 51 and n.39. In his review of Rodríguez Fernández, Joseph Shatzmiller remarks on the absence of documentary evidence concerning pawnbrokers and moneylenders active in León, Jewish Social Studies 42 (1980): $361-362$.

19 Irene Ruiz Albi, ed., La Reina Doña Urraca (1109-1126): cancellería y colección diplomática (León: Centro de Estudios e Investigación San Isidoro, 2003), doc. 62, pp. 453-454, doc. 81, p. 483. See also Pascual Martínez Sopena, "La circulation des objets en temps de guerre. Les années de la reine Urraca (León et Castille, vers 1110-1130)," in Objets sous contrainte: Circulation des objets et valeur des choses au Moyen Âge, ed. Laurent Feller and Ana Rodríguez (Paris: Publications de la Sorbonne, 2013), 257-281. Urraca's reputation as a despoiler is taken up by John Williams, "León and the Beginnings of the Spanish Romanesque," in The Art of Medieval Spain: A.D. 500-1200 (New York: The Metropolitan Museum of Art, 1993), 173; and Therese Martin, Queen as King: Politics and Architectural Propaganda in Twelfth-Century Spain (Leiden: Brill, 2006), 12-16. 


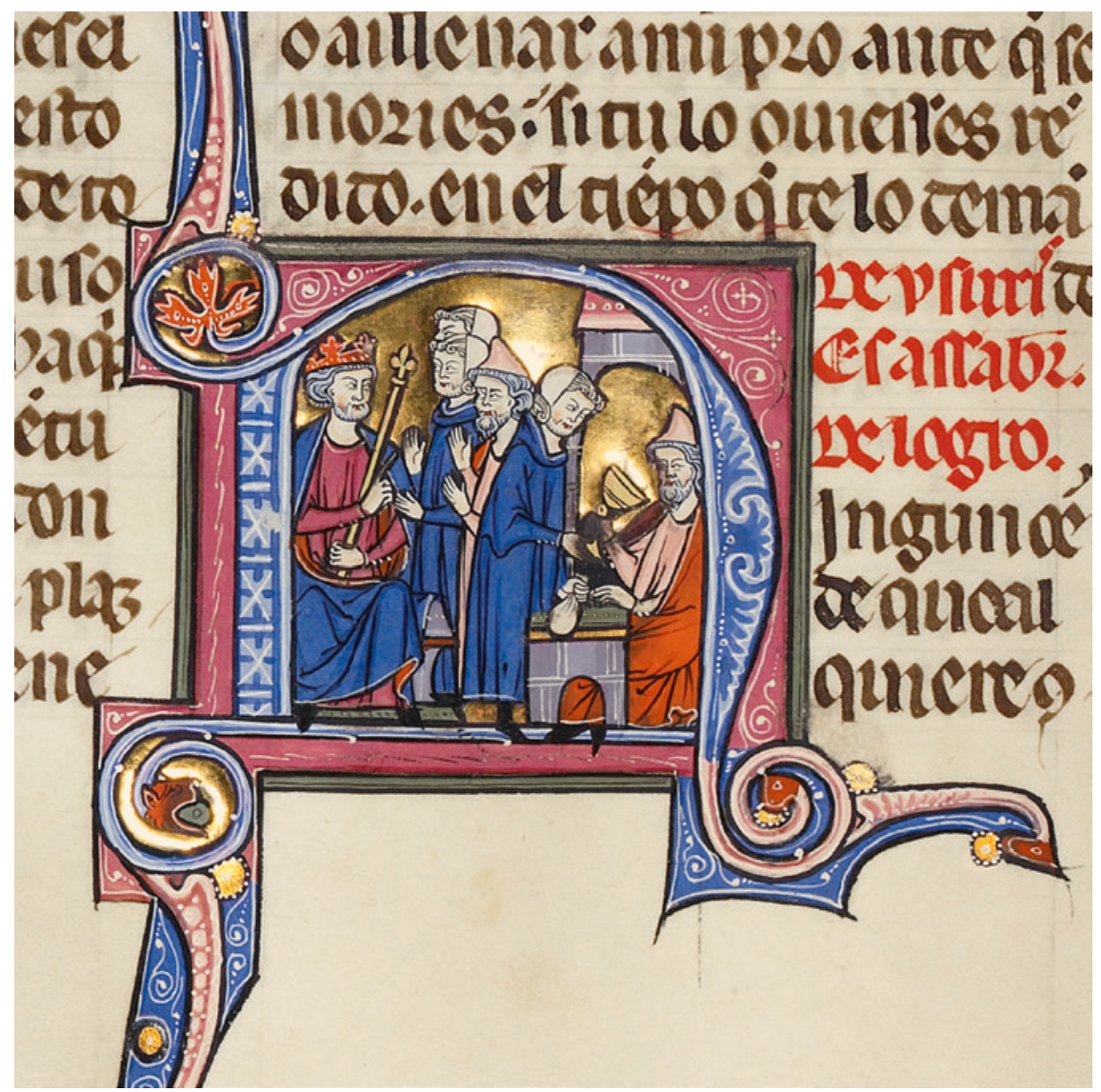

FIGURE 8.1 The Vidal Mayor, J. Paul Getty Museum, Ms. Ludwig XIV 6, 83.MQ.165., fol. 175v. DIGITAL IMAGE COURTESY OF THE GETTY'S OPEN CONTENT PROGRAM

nine marks of silver yielded by the cross were then paid to Pedro Peláez for the purchase of a war horse. Perhaps these local Jews - of Saldaña and Santa Olaja de la Vega respectively - were metalworkers or moneychangers active in the exchange, but perhaps not. The surviving documents merely record their presence ("presentibus christianis et iudeis de Saldania" and "et christianos de Barrio et iudeos de Ueiga"); they say nothing about their actions or professions. ${ }^{20}$ Furthermore, for León proper, Jewish loan agreements of any kind are rare-a situation remarked upon by Manuel Carriedo Tejedo in his

20 Ruiz Albi, La Reina Doña Urraca, doc. 62, pp. 453-454; doc. 81, p. 483. 


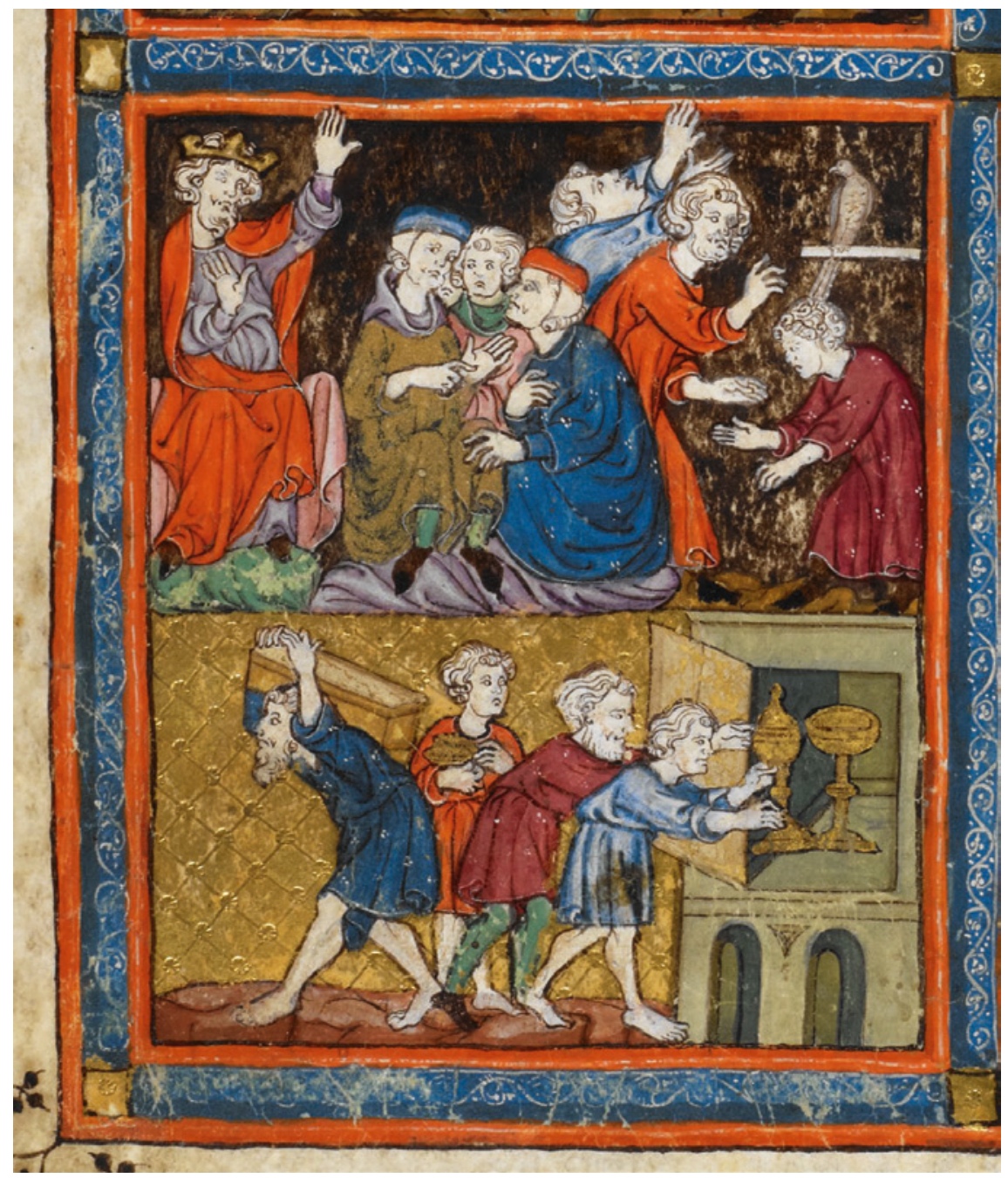

FIGU RE 8.2 The Golden Haggadah, folio 13r. Bottom left: "The Spoiling of the Egyptians and the Plague of Darkness."

SOURCE: (C) BRITISH LIBRARY BOARD, MS ADD. 27210

comprehensive 2012 study of documents dating from the years $1055^{-1230} .^{21}$ Given the lack of evidence, the treasury of San Isidoro as a topic of inquiry

21 Manuel Carriedo Tejedo, "Los judíos en el reino de León (1055-1230). Documentos y testimonios," in El mundo judio en la Península Ibérica: sociedad y economía, ed. Jorge SánchezLafuente Pérez and José Luis Avello Álvarez, 2nd ed. (Cuenca: Editorial Alfonsípolis, 2012), 20-151. Doc. 18o, p. 69, dated to June 13,1162 is a donation by Fernando II to the bishop 
defies expectations for predictable involvement of living Jews based on other comparable centers.

\section{$2 \quad$ Historical Jews in the Church Treasury}

A second expectation with regard to San Isidoro is that one might find relics of historical Jews contained within its treasury. This expectation stems from the understanding that in assembling a treasury, Christian royalty in Iberia was laying claim to other faith traditions and declaring itself superior to them. By collecting Old Testament and Holy Land relics, Christianity could be understood as connecting to but also superceding and correcting a flawed Judaism - the faith of its origin. ${ }^{22}$ Collection of these relics is not new to the eleventh century; precedent can be observed already in Pope Leo III's Sancta Sanctorum of Rome's Lateran Palace, which was named after the Tabernacle of Solomon's Temple. ${ }^{23}$ The collection of objects associated with King Solomon was particularly long-lived and geographically diverse, but relics associated with other revered Old Testament people and places were also collected. ${ }^{24}$ In the eleventh century, the Rod of Aaron and relics of Mt. Sinai were present in Eichstätt Cathedral and the Church of Saints Mary and Peter in Exeter. ${ }^{25}$ Possession of objects associated with the Holy Land or with biblically significant events may even have had special resonance in Iberia during the "Reconquest" which was thought to mirror contemporary efforts

of León. Among other goods, the king donates a loan which was obtained by the Jew Abolphazan, "Illud prestimonium quod ille iudeus Abolphazan obtinuit." The author notes the rarity of such activity in León.

Philippe Buc, "Conversion of Objects," Viator 28 (1997): 99-143, esp. 108-o9, has made this point regarding a horn of Islamic design which was turned into a reliquary containing the relics of Abraham, Isaac, Jacob, and Sarah.

23 Holger Klein, "Sacred Things and Holy Bodies: Collecting Relics from Late Antiquity to the Early Renaissance," in Treasures of Heaven: Saints, Relics, and Devotion in Medieval Europe, ed. Martina Bagnoli, Holger Klein, C. Griffith Mann, and James Robinson (New Haven: Yale University Press, 2010), 55-67, esp. 58. See also Herbert Kessler, "Sacred Light from Shadowy Things," Codex Aquilarensis 32 (2016): 237-270, who discusses the influence of Old Testament realia - including objects such as the Ark of the Covenant-on Christian thought and art.

24 Allegra Iafrate, "Opus Salomonis: Sorting Out Solomon's Scattered Treasure," Medieval Encounters 22 (2016): 326-378.

25 Julia M. H. Smith, "Eleventh-century Relics Collection and the Holy Land," in Natural Materials of the Holy Land and the Visual Translation of Place, 500-1500, ed. Renana Bartal, Neta Bodner, and Bianca Kühnel (Routledge: London and New York, 2017), 19-35. 
to reclaim Christian holy sites during the Crusades. ${ }^{26}$ Years ago, John Williams interpreted particular iconographic features of San Isidoro's Romanesque Portal of the Lamb as conveying a similar theological message by proclaiming Christianity's rightful inheritance of its Abrahamic legacy against Islamic claims to the contrary. ${ }^{27}$

In fact, Abraham - whom the Church Fathers believed to be the first Christian-may have experienced increased devotion after 1100 when the Crusaders captured Hebron where he, his wife Sarah, and their son Isaac were believed to have been buried. The site had been in Muslim hands since approximately the year 638 , and the tomb of the patriarch had been converted to a mosque. In the tenth and eleventh centuries, it remained a pilgrimage site for both Jews and Christians; the Muslim leadership even permitted a synagogue to be constructed there. ${ }^{28}$ The relics of Abraham, Isaac, Jacob, and Sarah were elevated by the clergy of Hebron in $1119 .{ }^{29}$ As Brett Whalen has pointed out, the appropriation of the patriarch's actual remains marked the culmination of a long-term theological Christian appropriation of the patriarchs. ${ }^{30}$

26 R.A. Fletcher, "Reconquest and Crusade in Spain c. 1050-1150," Transactions of the Royal Historical Society ser. 5, 37 (1987): 31-48. According to C. Erdmann, The Origin of the Idea of the Crusade (Princeton: Princeton University Press, 1977), 289, Pope Urban II regarded the Muslim-Christian conflict in Iberia to be similar to the First Crusade. Earlier, Pope Alexander II had announced an indulgence for troops participating in the Barbastro campaign. Erdmann, 137-138, points out that this is the earliest extant crusading indulgence. More recently, Xenia Bonch-Bruevich, "Ideologies of the Spanish Reconquest and Isidore's Political Thought," Mediterranean Studies 17 (2008): 27-45, gives a useful historiographic treatment of the subject including mention of Joseph O'Callaghan, Reconquest and Crusade in Medieval Spain (Philadelphia: University of Pennsylvania Press, 2003), who argues for a Reconquest ideology that is fueled primarily by religious rather than secular motivations.

27 John Williams, "Generationes Abrahae: Reconquest Iconography in León," Gesta 16/2 (1977): 3-14. An updated version was published as "Generationes Abrahae: Iconografía de la Reconquista en León," in El Tímpano románico: imágenes, estructuras y audiencias, ed. R. Sánchez Ameijeiras and J. L. Senra Gabriel y Galán (Santiago de Compostela: Xunta de Galicia, 2003), 155-180. For the development of the church's transepts and portals, see Therese Martin, "Recasting the Concept of the 'Pilgrimage Church:' The Case of San Isidoro de León," La Corónica 36/2 (2008): 165-189; José Luis Senra, "La paix durant la guerre: la conjoncture politico-religieuse et les espaces sacrés dans le royaume de León et Castille, ca. 1110-1127," Viator 47/2 (2016): 137-182.

28 Brett Whalen, "The Discovery of the Holy Patriarchs: Relics, Ecclesiastical Politics and Sacred History in Twelfth-Century Crusader Palestine," Historical Reflections / Réflexions Historiques 27 (2001): 139-176.

29 Buc, "Conversion of Objects," 108.

30 Whalen, "The Discovery of the Holy Patriarchs," 152. 
Contemporary interest in the Holy Land, the Holy Sepulcher, and the Hospitallers is evident in the patronage of Queen Urraca (r. 1109-1126). ${ }^{31}$ Such interests are also reflected in the treasury of San Isidoro in the arresting object known as the Portable Altar of the Infanta Sancha, dated 1144, which contains a long inscription naming the relics of individuals and sites from the Holy Land. ${ }^{32}$ The third item listed, after the relics of the Trinity and Mary, are those of the Blessed Patriarch Abraham. Two additional Old Testament figures are mentioned in the fourteenth-century inventory of the relics and indulgences at San Isidoro: "the bones of Samuel the prophet," and some "of the oak of Mamre under which Abraham dwelt."33

Despite this evidence, which in the case of the fourteenth-century inventory is documentary rather than physical, the treasury of San Isidoro contains relatively few objects connected with Jews or with the Old Testament, given their growing popularity in comparable centers. Contrast, for a moment, the Cámara Santa of San Salvador de Oviedo whose famed reliquary the ArcaSanta (seeChpt. 6, Figure 6.5) doubles down on its Old Testament references. ${ }^{34}$ First, there is

31 William R. Moore, "Religious Language and the Construction of Royal Power: León, 1037-1126," PhD diss., Columbia University, 2010, 18. See also Martin, "Recasting the Concept of the 'Pilgrimage Church'"

32 The full inscription appears in Jitske Jasperse, "Between León and the Levant: The Infanta Sancha's Altar as Material Evidence for Medieval History," in the present volume.

33 Santiago Domínguez Sánchez, Patrimonio cultural de San Isidoro de León. Documentos del siglo XIV, II.1 (León: Univers dad de León, 1994), 178-181, esp. 179. The inventory is document 9o, dated 1o August 1331: "los huesos de Samuel propheta; de la enzina (Manbré so que moró Abrahan)." My thanks to Therese Martin for her help with the inventory. For early Christian sources on the oak of Mamre and its cult, see Elizabeth Key Fowden, "Sharing Holy Places," Common Knowledge 8/1 (2002): 124-146, esp. 126, n.8.

34 Julie A. Harris, "Redating the Arca Santa of Oviedo," The Art Bulletin 77 (1995): 83-93. There has been much recent work on the reliquary comprising scholarship that features historical, art historical, and theological perspectives. The following have been helpful to me: Raquel Alonso, "El Obispo Arias y la apertura del Arca Santa de Oviedo: la reforma litúrgica antes del Concilio de Burgos (1080)," Medievalia 17 (2014): 79-102; Alonso, "El Corpus Pelagianum y el Liber Testamentorum Ecclesiae Ovetensis: las 'reliquias del pasado' de la Catedral del Oviedo y su uso propagandístico en la obra del Obispo Pelayo de Oviedo (1101-1153)," in Texte et Contexte. Littérature et Historie de l'Europe médiévale, ed. M.F. Álamichel and R. Braid (Paris: Michel Houdiard, 2011), 519-549; and Alonso, "Patria uallata asperitate moncium. Pelayo de Oviedo, el archa de las reliquias y la creación de una topografía regia," Locus Amoenus 9 (2007-2008): 17-29. See also Rose Walker, "Becoming Alfonso VI: The King, His Sister and the Arca Santa Reliquary," in Alfonso VIy el arte de su época, ed. Javier Martínez de Aguirre and Marta Poza Yagüe, Anales de Historia del Arte, vol. extra. 2 (2011): 391-412; Isidro Bango Torviso, "La renovación del tesoro sagrado a partir del Concilio de Coyanza y el taller real de orfebrería de León. El Arca Santa de Oviedo (1072)," in Alfonso VI y el arte de su época, 11-67, and Flora Thomas Ward, "Constructing 
its physical resemblance to the biblical Ark of the Covenant; second, there are its contents which include the rod of Moses which parted the Red Sea and manna supplied from Heaven during the Exodus; finally, there is the powerful attendant narrative of the Arca's own flight from the Holy Land to Spain..$^{35}$

The treasury of Toledo Cathedral offers yet another comparison. The Cathedral's inventory of 1338 mentions many objects in the treasury said to be of Jewish origin or manufacture. ${ }^{36}$ Some of the descriptive vocabulary used in the inventory refers to methods of decoration that were apparently associated with Jews: for example, a gospel cover is said to be ornamented with Jewish diaper work (diasper judio). ${ }^{37}$ Still other terms describe materials associated with or possibly made by Jews: the term çendal judio appears several times when describing the treasury's liturgical vestments, as do other textiles called xamete judio and seda judia. ${ }^{38}$ Further references to particular objects of clothing may imply that their appearance in some way characterized them as Jewish, for example, capas judias. ${ }^{39}$

the Cámara Santa: Architecture, History, and Authority in Medieval Oviedo," PhD diss., University of Toronto, 2014.

35 Recent conservation efforts in the Cámara Santa have allowed for a closer examination of the Arca Santa. See María Antonia Martínez Núñez, "Inscripciones árabes en la Catedral de Oviedo: El Arca Santa, la Arqueta del Obispo Arias y la Arqueta de Santa Eulalia," Territorio, Sociedad y Poder 11 (2016): 23-62; César García de Castro Valdés, "Datos y observaciones sobre el Arca Santa de la Cámara Santa de la catedral de Oviedo," Nailos 3 (2016): 121-163; and García de Castro Valdés, El Arca Santa de la Catedral de Oviedo (Aguilar de Campoo: Fundación Santa María la Real, Centro de Estudios del Románico, 2017). Lucy Pick uses the inscription on its lid, among other factors, to connect it to Urraca Fernández in Her Father's Daughter: Gender, Power, and Religion in the Early Spanish Kingdoms (Ithaca: Cornell University Press, 2017), 188-192.

36 Luis Pérez de Guzmán, "Un inventario del siglo XIV de la catedral de Toledo (La Biblia de San Luis)," Boletín de la Real Academia de la Historia 89 (1926): 373-419. The inventory is a paper document in the Archivo Histórico Nacional. My thanks to Tom Nickson for providing me with a copy. Nickson discusses the contents of Toledo's treasury in Toledo Cathedral: Building Histories in Medieval Castile (University Park, PA: The Pennsylvania State University Press, 2015), esp. 116, 124-130.

37 Pérez de Guzmán, "Un inventario del siglo XIV," "ítem un euangelistero muy fermoso con cubiertas de diasper judio," 389 .

38 Pérez de Guzmán, “Un inventario del siglo XIV," “Item una casulla de xamete prieta orofresada con orofresada con orofres angostos afforrada de çendal judio," 383; "Item una estola e un manipulo estoriado con oro aforrado en çendal judio," 384; "Item casulla túnica dalmática de xamete judio con orofres anchos de londres," 403; "Item una casulla de xamete judio con orofres viejo," 405; "Item una toca de sseda judia con oro" and "Item otra toca de sseda judia con llauores de oro," 413.

39 Pérez de Guzmán, "Un inventario del siglo XIV," "Item dos capas judias la una a rrosas e la otra ssin lauores. Item una capa judia afforrada en cendal amariello con orofreses de monpesler," 392. 
No less significant to this topic is a mysterious small brass container in Toledo Cathedral's sacristy. ${ }^{40}$ It is generally believed to have once held phylacteries-tefillin - due to its similarity to surviving phylactery cases from North Africa. ${ }^{41}$ The case's lid is inscribed with the name Isaac Caro written in Hebrew letters. Caro was a noted Jewish scholar and teacher, although his ownership of the case, in my opinion, is a matter for further debate. The provenance is complicated by the fact that the object is thought on stylistic grounds to date from the thirteenth or fourteenth century; Caro himself was born in Toledo in 1458 and left Spain for Lisbon in 1492. Is it possible that the name was inscribed when Caro received the case from an earlier owner? Or was it added later to increase the case's value by associating it with a local Jewish luminary? Nothing tells us when and under what circumstances the case entered the Toledan treasury. Nor do we know what viewers, many of whom may have been Toledo's "new Christians," were meant to think when they saw this Jewish liturgical object-inscribed with the name of a prominent member of the community-displayed in the Cathedral treasury.

If, as Therese Martin asserts the creation of a medieval treasury provides a material witness that reveals the interests, possibilities, and aspirations of those who established it, ${ }^{42}$ one might interpret the collection, adaptation, and display, for example, of Islamic goods as generated by triumphalist motives during a time of war-or by a simple delight in their magnificence. What meaning is conveyed by these objects' recognizably Islamic forms or decorations? The same complexity surrounds the use of recognizably Islamic architectural motifs in Christian buildings. Martin initially interpreted the polylobed arches within the church of San Isidoro as referring to the Great Mosque of Toledo, which had been converted to a cathedral shortly after the city was taken in 1085 by Queen Urraca's father, Alfonso vi. More recently, she suggested that "rather than representing triumphalism or conquest, the polylobed arches speak the language of rulership, expressing a concept that encompasses all the inhabitants of the Iberian

40 Catalogue entry by G. Pik, in Ysabel, la reina católica. Una mirada desde la Catedral Primada, ed. Ángel Ballesteros Gallardo (Toledo: Instituto Teológico San Ildefonso, 2005), 322-323, and catalogue entry by Clara Bango García in Memoria de Sefarad (Toledo, Centro Cultural San Marcos, 2004), 180. The box measures $11 \times 9 \times 2.5 \mathrm{~cm}$.

41 Tefillin, containers for parchment verses from the Torah, are traditionally bound to the forehead and arm by observant Jewish men while saying their weekday morning prayers. Wearing tefillin is a ritual to remind the individual of God's deliverance of the Jews from Egypt.

42 Therese Martin, "Caskets of Silver and Ivory from Diverse Parts of the World: Strategic Collecting for an Iberian Treasury," in Chpt. 2 of this volume. 
Peninsula." ${ }^{33}$ In concert with Martin's efforts to extend this language of rulership to the treasury of San Isidoro, I pose the following questions: could there be a visual equivalent to the polylobed arches for the Peninsula's Jews? Might the collection and display of objects with a Jewish connection-either visual or intrinsic-confer some particular status on the institution which holds them? Is the collection and display of such objects done deliberately, or is it simply of question of what is available at the time of assembly? In the treasury at San Isidoro, living Jews are superseded by biblical prototypes as a few Old Testament relics are collected and colonized by the Christian present.

There is one remaining wild card in all of this: the numerous textiles used to line and even, in some instances, to cover reliquaries and other containers in the treasury. We must consider the possibility that some of the precious fabrics in San Isidoro may be of Jewish manufacture. There are, as discussed above, several references to Jewish fabrics in the 1338 inventory of Toledo Cathedral. Among the sources that attest to Jewish mastery of this art and dominance in the silk trade, we have the Book of Tradition by Abraham ibn Daud (ca. 116o). He writes the following about the ibn Jau brothers, Jews from al-Andalus at the turn of the eleventh century:

They became successful in the silk business, making clothing of high quality and pennants that are placed at the tops of standards of such high quality as was not duplicated in all of Spain. They brought presents to King Hisham and to King al-Mansur ibn Abi 'Amir, his guardian, with the result that King al-Mansur became very fond of Jacob b. Jau. ${ }^{44}$

In the past, art historians have tended to see the silks lining the reliquaries in church treasuries through the lens of conquest and appropriation, characterizing them as Islamic in manufacture but enlisted to serve a Christian purpose. ${ }^{45}$

43 Therese Martin, “The 'Unthinkable' Patronage of a Code-Switching Queen," unpublished paper delivered at the 104th Annual Conference, College Art Association, Washington, D.C., 4 February 2016.

44 For Jacob ibn Jau and his brother Joseph, merchants and manufacturers of silk, see Gerson Cohen, A Critical Edition with a Translation and Notes of the Book of Tradition (Sefer haqabbalah) by Abraham Ibn Daud (Philadelphia: Jewish Publication Society of America, 2010), 68-69.

45 Julie Harris, "Muslim Ivories in Christian Hands," Art History 18/2 (1995): 213-221, and Avinoam Shalem, Islam Christianized: Islamic Portable Objects in the Medieval Church Treasuries of the Latin West (Frankfurt: Peter Lang, 1996) examined the question of reuse of Islamic objects in light of Muslim-Christian relations. For a different approach, see Glaire Anderson, "Sign of the Cross: Contexts for the Ivory Cross of San Millán de la Cogolla," Journal of Medieval Iberian Studies 6/1 (2014): 15-41; and Mariam Rosser-Owen, 
In recent years, however, our thinking about these luxury textiles has taken a more nuanced approach. ${ }^{46}$ If some of these textiles were known to be of Jewish, rather than of Muslim or Christian manufacture, would this change our understanding of them?

It has become commonplace in academic writing in a range of fields, including medieval Art History, to make a distinction between real Jews and hermeneutical Jews - the latter a term coined by Jeremy Cohen to describe a constructed notion of Jews based on theological dogma rather than on lived experience. ${ }^{47}$ This discourse and its implications inform recent studies by Pamela Patton, Nina Rowe, and others; Cohen's distinction is useful because it helps to explain the overtly anti-Jewish iconographies that appear even when relations between living Jews and Christians are relatively peaceful and cooperative. ${ }^{48}$

In this paper, I suggest the term imaginary Jews rather than hermeneutical because not everyone interacting with Jews or thinking about their Jewish neighbors in medieval León would have maintained so rigid a dichotomy between what they observed and what theology had taught them. For example, some of what medieval Iberians thought about Jews may have been an amalgam of hermeneutics and folklore or literary motifs, which may or may not have developed alongside institutionally sanctioned biblical interpretation. Imaginary therefore works better as a term because it takes into account majority religious doctrine on Judaism together with other notions that may have informed people's perceptions of what Jews and Judaism were all about. Further, it is a useful concept for dealing with figures of Jewish origin, like

"Islamic Objects in Christian Contexts: Relic Translation and Modes of Transfer in Medieval Iberia," Art in Translation 7/1 (2015): 39-64.

46 María Judith Feliciano, "Medieval Textiles in Iberia: Studies for a New Approach," in Envisioning Islamic Art and Architecture: Essays in Honor of Renata Holod, ed. David J. Roxburgh (Leiden: Brill, 2014), 46-65.

47 Cohen, Living Letters of the Law, 3-6.

48 Nina Rowe credits Jeremy Cohen for providing a model for her art historical research in The Jew, the Cathedral and the Medieval City: Synagoga and Ecclesia in the Thirteenth Century (Cambridge: Cambridge University Press, 2011), 7. Pamela Patton also acknowledges the usefulness of Cohen's conceptual image of the "hermeneutical Jew" in Art of Estrangement, 12. Another historian working with a similar dichotomy (and credited by Rowe, 7) is David Nirenberg, who uses the terms "figures of thought" and "figures of flesh" in his "Figures of Thought and Figures of Flesh: 'Jews' and 'Judaism' in Late-Medieval Spanish Poetry and Politics," Speculum 81/2 (2006): 398-426. 
Abraham or Moses, about whom legends, liturgy, and even relics accrued to their historical reality.

Regardless of the term employed, one finds medieval León to be a place where the contradiction between theologically sanctioned notions of Judaism and interactions with real Jews is readily apparent. In her recent book, Maya Soifer Irish illustrates this contradiction by contrasting the words of Santo Martino of León, written in the late twelfth century from his cell in San Isidoro, "O, Jews, it is for the sake of your own salvation that I admonish you time and again, for I wish you to become part of the body of Jesus Christ," to the words of Abbot Gutierre of the nearby monastery of Sahagún who, concerned about finding additional burial space for the local Jewish community under his jurisdiction wrote: "All men are our neighbors, whether Jews or pagans; for one should not act wrongfully with anyone ..." 49

Soifer Irish points out that Martino's statement was not directed to his actual Jewish neighbors in León but was instead a theological abstraction. ${ }^{50}$ She writes, "This apparent absence of convergence between the theoretical discourse and the lived experience was perhaps the most salient characteristic of the relations between Synagoga and Ecclesia in Spain not only during the twelfth century, but also in the 1200s, and even beyond."51

My charge for the Treasury project was to investigate the connection between Jews and the treasury of San Isidoro of León. What I learned is the following: if you seek "real" Jews connected to a religious institution in León you will not find them at San Isidoro but at the Cathedral. This connection was initially forged during the reign of Fernando I (1037-1065), the figure who, in partnership with his wife Sancha, is generally credited with assembling the core of San Isidoro's treasury. ${ }^{52}$ Although the original document no longer exists, a letter of 1074 written by Bishop Pelayo of León states that Fernando granted 500 sueldos of pure silver to the Cathedral. ${ }^{53}$ This grant was said to

49 Soifer Irish, Jews and Christians, 77-78.

50 Soifer Irish, Jews and Christians, 77, n.1.

51 Soifer Irish, Jews and Christians, 79.

$5^{2}$ Fernando and Sancha's patronage of the treasury, based on the twelfth-century document recording their 1063 donation, is now being reassessed, following the pioneering article by María Encarnación Martín López, "Un documento de Fernando I de 1063: ¿Falso diplomático?" in Monarquía y sociedad en el reino de León. De Alfonso III a Alfonso VII, II, Fuentes y Estudios de Historia Leonesa, 118 (León: Centro de Estudios e Investigación San Isidoro, 2007), 513-540. See Therese Martin's discussion in Chpt. 2 of in this volume, "Caskets of Silver and Ivory."

53 Rodríguez Fernández, La judería de la ciudad de León, 181-182, doc. 49; Soifer Irish, Jews and Christians, 94-95. 
have originated during the episcopate of Bishop Alvito, Pelayo's predecessor, and was to have come from the Jews' rent-de censu iudeorum. Bishop Alvito reserved 300 sueldos of pure silver from this Jewish rent for the use of the episcopal see, while the remainder was granted to the clerics of the Cathedral. ${ }^{54}$ Thus, the Crown shared income gathered from its resident Jewish community with ecclesiastical institutions in the realm. According to Soifer Irish, who has written extensively on the subject, Fernando's action, taken in the mideleventh century, would become standard procedure among Castilian and Leonese monarchs in later years. ${ }^{55}$

To my mind, the grant de censu iudeorum initiated by Fernando I was significant for reasons beyond the financial boost it offered its recipients; ultimately, the assignation of funds was also symbolic in nature. During the next fifty years, it became customary for bishops of León to assign a portion of their share of Jewish taxes for one particular purpose: the nocturnal illumination of several altars in the Cathedral. ${ }^{56}$ We can clearly trace this allocation in the documents. In 1092, Bishop Pedro designated an additional twenty sueldos for the same purpose. ${ }^{57}$ In 1120, Bishop Diego allocated fifty of the 500 sueldos paid to the church by the Jews of Puente Castro for lighting the altars of St. Mary, St. Salvador, and St. John the Baptist. Soifer Irish points out that the community funding these candles was not named until this particular document in which Bishop Diego mentions the customary tribute paid by the "Jews of the Castle" - that is, Puente Castro - annually on the feast of St. Martin. ${ }^{58}$ The land these Jews inhabited was royal property; their rent was owed the monarch. By the end of the twelfth century, in addition to 5oo sueldos of Jewish rent, the bishop of León was also receiving deluxe products likely made by Jewish artisans living in the fortress. ${ }^{59}$

54 Soifer Irish, Jews and Christians, 21 and 94-95; and Soifer Irish, "The Castilian Monarchy and the Jews (Eleventh to Thirteenth Centuries)," in Center and Periphery: Studies on Power in the Medieval World in Honor of William Chester Jordan, ed. Katherine Jansen, G. Geltner, and Anne Lester (Leiden: Brill, 2013), 39-49, at 41.

55 Soifer Irish, "The Castilian Monarchy and the Jews," 42.

$5^{6}$ Soifer Irish, Jews and Christians, 95, n.70.

57 Rodríguez Fernández, La judería de la ciudad de León, doc. 52, 186-188.

58 Soifer Irish, Jews and Christians, 95. Rodríguez Fernández, La judería de la ciudad de León, doc. 55, 189-191, "et quinquaginta solidos de quingentis quos reddunt nobis iudei de Castro in festivitate beati Martini, more antiquo." The document was witnessed by Archbishop Bernard of Toledo and Queen Urraca (Hiberie imperatrix), among others.

59 Soifer Irish, Jews and Christians, 95, n.71. Rodríguez Fernández, La judería de la ciudad de León, doc. 59, 192-194, "quingentos solidos regie monete et unam pellem optimam et duos godomecios percipere consuevit." Godomecios are generally understood to be embossed leather hangings. 
As stated previously, beyond the financial specifics of the annual allocation of Jewish rent, its apparently symbolic nature is also highly significant. As Soifer Irish recently pointed out, the Jews of Genoa, Italy were also paying an annual tribute for the illumination of the high altar in the church of San Lorenzo. She reasonably asks whether the allocation of Jewish money for the illumination of church altars is coincidence or a deliberately symbolic act repeated elsewhere in Mediterranean settings. ${ }^{60}$

An art historical perspective answers in the affirmative, and it is also useful in reminding us of the theological principles underlying these donations; such ideas gave rise to numerous sculpted figures of the defeated Blind Synagogue-paired with her triumphant counterpart Ecclesia—in churches across Europe beginning in the thirteenth century. This iconography, carefully analyzed by Nina Rowe and other art historians, embodies the church's official view of the Jews, who refuse or are unable to see the truth in Christianity. ${ }^{61}$ Rowe's monograph, which focuses on the sculptural programs of the cathedrals of Reims, Bamberg, and Strasbourg, also treats the iconography in other media before its development as a theme in Gothic portal sculpture. No longer embodying an ancient theological abstraction, these sculptural Synagoga and Ecclesia figures become all the more powerful, given the aesthetic possibilities inherent in Gothic naturalism. Moreover, Rowe's work reveals these Synagoga and Ecclesia figures to be representatives of a longlived iconography; the reformulation and activation of this imagery was dependent on the close proximity of living Jews, whose visible creativity and relative prosperity were viewed with suspicion by those in power.

Although largely a northern European phenomenon, the Blind Synagogue also appears as part of the sculptural program of the western facade of León Cathedral, the most French of all Gothic buildings in Spain. ${ }^{62}$ The figure appears

6o Soifer Irish, Jews and Christians, n.70.

61 Rowe, The Jew, the Cathedral and the Medieval City is the most comprehensive study of the Synagoga and Ecclesia sculptures in their theological, art historical, and political contexts. A central preoccupation of Sara Lipton's scholarship has been exploring the connections between Jews and vision that medieval Christendom found useful both in text and image. See, for example, Lipton, "Unfeigned Witness: Jews, Matter, and Vision in Twelfth-Century Christian Art," in Judaism and Christian Art: Aesthetic Anxieties from the Catacombs to Colonialism, ed. Herbert Kessler and David Nirenberg (Philadelphia: University of Pennsylvania Press, 2011), 45-73; and Lipton, Dark Mirror: The Medieval Origins of AntiJewish Iconography (New York: Metropolitan Books, 2014).

62 For the Cathedral of León and its decoration, see the studies in La Catedral de León en la Edad Media: Actas, León, 7-11 de abril de 2003, ed. Joaquín Yarza Luaces, María Victoria Herráez Ortega, and Gerardo Boto Varela (León: University of León, 2004). For architectural issues, see Henrik Karge, "La arquitectura de la Catedral de León en el contexto del gótico europeo," 113-144. Two essays address the sculpture in particular: Willibald 
on the Portal of St. John the Baptist, which was carved between 1255-1275. While the figure of Ecclesia stands triumphant within the protection of the porch, Synagoga appears on its outer edge - abraded by time but still visible as one who is rendered blind and deaf by a pair of demonic dragons (Figure 8.3). Rowe's recognition of the social realities - as much as theological underpinningsaddressed by this iconography in Northern Europe also informs the pair's inclusion in León's sculptural program: it is not merely a question of importing a French cathedral with sculpture attached. These Synagoga and Ecclesia figures respond to the presence of real Jews in the city of León; the portal's complex iconographical program is characterized by art historian Rocío Sánchez Ameijeiras as persuasive visual rhetoric directed toward the Jews. ${ }^{63}$ Though its sculpture was implemented after the destruction of the Puente Castro community mentioned in the census documents, the cathedral remains an ideological locus in which Jews were paying to illuminate its altars and, by extension, to shine a light on the triumphal truth of Christianity. ${ }^{64}$ A theological discussion regarding the true inheritance of Abraham's covenant with the Lord was begun on San Isidoro's Portal of the Lamb; over a hundred years later it was continued at the Cathedral of Santa María. In both cases, an iconography based on theological abstractions was enlivened by the presence of living Muslims and Jews whose faiths embraced alternative readings of sacred history.

San Isidoro's architectural language, its decoration, and the numerous objects in its treasury were supplemented by a series of miracles performed by its patron saint Isidore which reinforced notions of patrimony over the Kingdom of León's non-Christian residents. In his lifetime, Isidore (d. 636) was known as a scholar, theologian, and Archbishop of Sevilla whose tract De fide catholica contra Iudaeos laid the groundwork for some anti-Jewish elements of canon

Sauerländer, "La escultura de la sede leonesa a la luz de los grandes talleres europeos," 177-202, and Rocío Sánchez Ameijeiras, "Discursos y poéticas en la escultura gótica leonesa del siglo XIII," 203-240.

63 Rocío Sánchez, "The Faces of the Words: Aesthetic Notions and Artistic Practice in the Thirteenth Century," in Gothic Art and Thought in the Later Medieval Period: Essays in Honor of Willibald Sauerländer, ed. Colum Hourihane (Princeton: Princeton University and The Pennsylvania State University Press, 2011), 100, n.38.

64 In this vein, one might also consider the seven-branched candlestick (menorah) donated in 1099 to San Pedro de Eslonza by Urraca Fernández, eldest daughter of Sancha and Fernando. Pick, Her Father's Daughter, 184, writes that this candlestick and earlier examples such as that in Essen were "created with the idea of showing that the Christian Church was the true heir to the Temple of Solomon." 


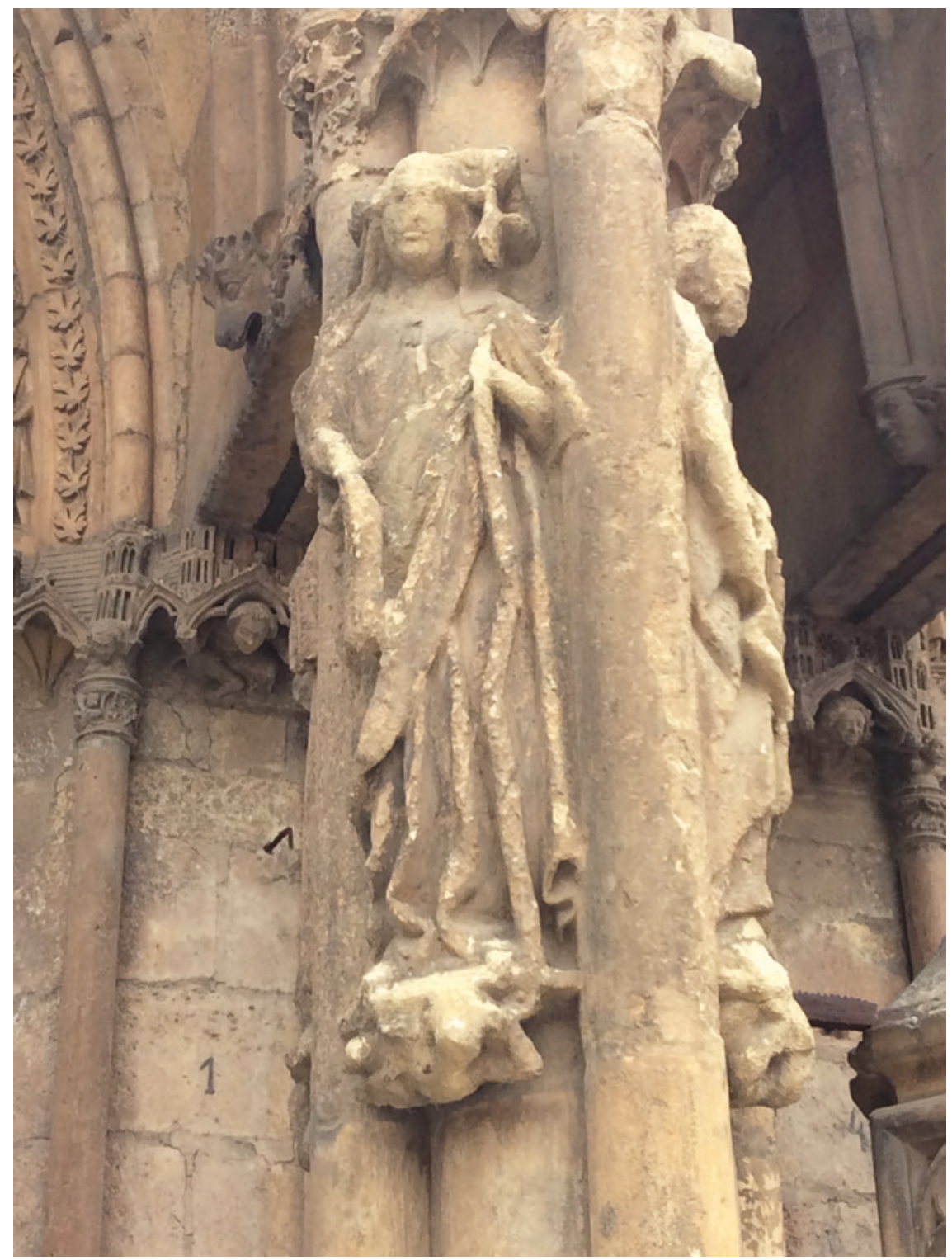

FIGURE 8.3 Blind Synagogue, west facade, Portal of St. John the Baptist, Cathedral of Santa María de la Regla, León.

PHOTO: PAMELA A. PATTON 
law. ${ }^{65}$ However, this facet of Isidore's ouevre does not seem to have been highlighted during the period in question. The Miracles of St. Isidore, written in the early thirteenth century by Lucas of Tuy (d. 1249), reveals how Isidore's character transformed as his cult responded to the political, social, and theological realities of the Middle Ages. About one hundred years before Lucas's Miracles, Bishop Pelayo of Oviedo's Chronicle of the Leonese Kings (Chronicon regum Legionensium) described a miracle in which water flowed through the stones in front of the altar of St. Isidore for three days following the death of Alfonso VI. Pelayo tells us that "This was seen by all the citizens, both by the nobles and by those not of noble birth ..." and that the clergy went in procession from the Cathedral to the altar of St. Isidore "accompanied by all the citizens-men and women ...."66 In Lucas's account, Isidore has expanded his audience and diversified his works; in the Miracles he emerges as healer, Reconquest warrior, supporter of worthy rulers, as well as becoming a saintly persona for all of León's inhabitants: rich and poor, but also Christian, Muslim, and Jewish. ${ }^{67}$

Jews figure in the narratives of several of these miracles. For example, in Chapter XIV a rich and rebellious Jew hiding out in the church of San Isidoro witnesses the healing of a paralyzed man. In Lucas's account, the building itself plays a significant role; the Jew chose it as his hiding place because he feared King Alfonso and felt that the only way to escape his wrath was to hide in the church dedicated to his special patron Isidore. ${ }^{68}$ After witnessing the paralytic's miraculous healing, the Jew and his family were baptized. Lucas

65 For Isidore's stance on the Jews including a discussion of the relevant historiography, see Cohen, Living Letters of the Law, 95-122. See also Bat-sheva Albert, "Isidore of Seville: His Attitude towards Judaism and His Impact on Early Medieval Canon Law," The Jewish Quarterly Review 80/3-4 (1990): 207-220.

66 Simon Barton and Richard Fletcher, The World of El Cid: Chronicles of the Spanish Reconquest (Manchester: Manchester University Press, 2000), 86.

67 Lucas de Tuy, Milagros de San Isidoro, ed. José Manuel Martínez Rodríguez (León: Universidad de León and Cátedra de San Isidoro, 1992). Patrick Henriet is currently working on a scholarly edition of the miracles. For his preliminary work, see Henriet, "Lucas of Tuy," in Christian-Muslim Relations. A Bibliographical History, vol. 4 (1200-1350), ed. David Thomas and Alex Mallet (Leiden: Brill, 20o9), 271-279; and Henriet, "Rex, lex, plebs. Les miracles d'Isidore de Séville à León (xi-xiii siècles)," in Mirakel im Mittelalter: Konzeptionen Erscheinungsformen, Deutungen, ed. Martin Heinzelmann, Klaus Herbers, and Dieter Bauer (Stuttgart: Franz Steiner, 2002), 334-35o. See also Javier Pérez-Embid Wamba, "Hagiografía y mentalidades en el siglo XII: los 'milagros de San Isidoro de León'," in Las Fiestas de Sevilla en el siglo XV: otros estudios (Madrid: Deimos, 1991), 413-444. Pérez-Embid, 422 and 425, discusses Lucas's attitude toward miracles concerning Muslims and Jews.

68 Martin, "Recasting the Concept of the 'Pilgrimage Church'," 179-181, discusses the prominence given to the building in Lucas's Miracles. 
tells us that he then made many donations to the church of San Isidoro and, for the rest of his life, preached in the kingdom's synagogues. Many additional Jews were converted due to his efforts.

Chapter XV of the Miracles of Saint Isidore recounts another miracle with cross-cultural implications. In his account, Lucas tells us that Christians, Jews, and Muslims celebrated together when Isidore healed a mute youth who, while hopelessly lost in the city, somehow found himself in the church of San Isidoro. ${ }^{69}$

Patrick Henriet has observed that St. Isidore's actions here take on a civic dimension in which members of all religions participate in celebrating the miracle. $^{70} \mathrm{~A}$ similar collective display appears in the mid twelfth-century Chronica Adefonsi Imperatoris when Christian nobles, Saracens, and Jews went out of Toledo to greet Alfonso VII, carrying drums, harps, and psalteries. ${ }^{71}$ These accounts, whether they be religious or secular in origin, display the superiority of Christianity over other faiths as they depict the realm's Jews, Muslims, and Christians united in celebration. Whether a similar message might have been conveyed solely by the objects in San Isidoro's treasury remains a matter for further study.

Postscript

An unexpected coda to the story of San Isidoro and the Jews is revealed by a document in the Archivo General of Simancas dated 14 September 1495. Three years after the last Jews were expelled from the territories ruled by the Catholic Monarchs Ferdinand and Isabella, the sinagoga mayor of León's resident Jewish community was donated to the Monastery of San Isidoro by royal decree. ${ }^{72}$

69 Chapter XVII describes visits by Muslims and Jews to the empty tomb of Isidore in Sevilla after miracles occurred there.

70 Henriet, "Lucas of Tuy," 274.

71 Cited by Nickson, Toledo Cathedral, 180, Chronica Adefonsi Imperatoris, Book Two, chapter 62: "When all the people heard that the emperor was coming to Toledo, all the nobles among the Christians, Saracens, and Jews and all the people of the city went far out of the city to greet him with drums, harps, psalteries, and all kinds of musick, each one of them in their own language praising and glorifying God...." The italicized words come from Daniel 11:5, 7, 10, and 15. Barton and Fletcher, The World of El Cid, 229.

72 The document is Archivo General de Simancas, Registro General de Sellos, fol. 269. See Moreno Koch, "El destino de la sinagoga mayor," 66; and Justiniano Rodríguez Fernández, Las juderias de la provincia de León (León: Centro de Estudios e Investigación San Isidoro, 1976), 428-429, n.1. Muñoz Solla, "Nuevas noticias sobre la sinagoga mayor de León," found a document in the Royal Chancellory of Valladolid which was issued as a result of a legal dispute between the Monastery of San Isidoro and an individual regarding ownership of the synagogue's portal. 
There were no longer any real Jews living in the city. And with the concession of their former synagogue to San Isidoro, León's Jews finally became the theological abstraction addressed by its treasury some four hundred years earlier.

\section{Acknowledgments}

Republication of this study in the present volume was supported by the Index of Medieval Art (Princeton University) and The Medieval Iberian Treasury in Context: Collections, Connections, and Representations on the Peninsula and Beyond (National Research Challenge Grant, Spanish Ministry of Science, Innovation, and Universities, AEI/FEDER, RTI2018-o98615-B-Ioo, 2019-2022, PI Therese Martin). 